\title{
DIFFERENTIATED TEACHING STRATEGIES WITH CHILDREN WITH LEARNING DIFFICULTIES
}

\section{Prof. Ass. Dr. Shemsi MORINA}

Universit of Prizren “Ukshin Hoti”, Faculty of Education, shemsi.morina@ uni-prizren.com

Article history:
Accepted O1 October2019
Available online 31 December 2019
Keywords:
Teaching
learning
learning difficulties
multiply intelligences
different styles of learning
differentiated teaching
qualitative learning.

\begin{abstract}
A b s t r a c t
Teaching process every day and more is changing with a strong evolution, where the use of methods, forms and multiple techniques are transforming teaching in a complex and difficult process on the other hand the teaching process is faced today with a large number of exception and contradiction as:
\end{abstract}

a) Teachers often give students the task of exercises, for solution of which required knowledge of many subjects, despite the knowledge provided by the teacher were only on their case, so in this respect should be paid special attention to all stages through which ensure quality teaching and successful learning.

b) Teachers should be familiar with: difficulties, styles, interests, needs, trends and psychological abilities of each student in order to ensure their walk confidently ahead.

c) On the other hand they often have to break and be dedicated to a group of advanced students who have interests much broader than the rest of the class, in this regard have the skills, but the rest of the children have difficulties therefore require constant supervision and help of teachers. These are some of the reasons that make teaching as a difficult and complex process. The teaching process as the learning had their history of development. Therefore they passed through the different stages being perfectly constantly.

From the very cognitive of these issues, it was concluded that both these processes are correlated with each other, which makes it even more complicated ( Raçi, A. Gashi, Sh. 2001: 3). Precisely for these reasons, studies and research on teaching and learning have been and are many today. These studies, as well as the interest accrued so teachers, psychologists, and experts in other fields, coupled with the fact that teaching and learning are continuous processes, such as understanding about them cannot ever finish ( QTKA, 2005: 13 ).

\section{Introduction to Search and Research Methodology}

\section{Presentation of the Problem}

Ongoing changes in the field of education, especially in the aftermath of war in Kosovo, had intended raising the quality of all levels of education, although the reality today shows an unsatisfactory situation in schools in Kosovo. Every day more and more in our schools is an increase of children who have difficulties in learning the language prior notions, mathematical skills. In his book, differentiated teaching "(Tomlinson, 2005: 51) gives practical advice on how to approach and be successful with children with learning difficulties in the learning process, based on the belief that all children They can learn and can be successful, but to do so depends on the insistence of teachers to achieve success, and confidence in the abilities of each child. According to him the basic idea of differentiated teaching is that teachers need to consider not only the subjects that give, but also children. Results in teaching, should be seen as an important element of experience in the work of a teacher. The degree of 
preparation and knowledge of the changes that have children in language, socioeconomic status, race, ethnic background, differences in strengths and weaknesses, abilities and learning difficulties - are the key to success in teaching. Many teachers feel that grades must include students with different needs, with different educational levels, with different interests and learning styles. In this way, to benefit from diversity, not to disregard it, teaching must necessarily be differentiated.

Under current conditions, as well as the modalities of teaching that apply now, where the inclusion of students with disabilities, but also the number of children with $\mathrm{SN}$, is growing every day more and more, seen as a necessity increase the accountability of teachers to be we provide quality education for all children, as well as adequate preparation for life and work.

Such a goal requires the fulfillment of certain conditions as provided in the school practices of other countries as:

- Teachers competent, responsive and well trained to work with children with S.V. and V.N. and trained in pedagogical and psychological terms:

- Customization of the curriculum;

- Tools and diverse enough concretized;

- Number of students in the class to be reasonable;

- Functionality of psychological and pedagogical service;

- Cooperation Permanent subjective factors.

Kosovo in school reality, some of the causes that are impossible implementation of differentiated instruction are:

- Overcrowded curriculum, and disproportionate to the psychophysical capabilities of children;

- Lack of adequate training of teachers, implementation of differentiated instruction;

- The very high number of students in classes, especially in urban areas;

- Short residence time student in school;

- Not great interest of parents for child's achievement in school;

- Lack of consulting services in school

\subsection{Hypothesis}

Today the process off teaching in our schools about his adaptation, the specifications of each child is presented with various defects. Rise of hypotheses, analysis and confirmation, or not in terms of the knowledge and attitudes of teachers about the necessity of implementing the teaching of the differential in our schools, and factors affecting the teaching in our schools will addressed step by step in this search.

The basic hypothesis; Differentiated Teaching and individual influences more in overcoming difficulties in learning, compared with other types of teaching;

\section{Auxiliary hypotheses:}

Auxiliary hypotheses 1: Women Educationalists auxiliary hypotheses, evaluate the usefulness and efficiency more differentiated teaching, compared with male teachers.

Auxiliary hypothesis 2: Teachers with higher education level, the more productive estimate of differentiated instruction, compared to teachers with lower levels of education.

Auxiliary hypothesis 3: private school teachers have the knowledge, and show the highest level of alert in the implementation of differentiated instruction, compared with public school teachers.

Auxiliary hypothesis 4: urban teachers, knowledge, and show the highest level of alert in the implementation of differentiated instruction, compared with teachers in rural areas.

\subsection{Methodology}

The aim of this study is to diagnose the knowledge, and the willingness of teachers to implement the mode of teaching differentiated children with learning difficulties, and the conditions and technologies that provide schools for successful implementation of this modality, about adapting depending on: the needs, styles, intelligences and diverse difficulties faced by children with SN in the learning process of knowledge in the learning process. This chapter shall submit a research strategy is selected, the instruments used and the population from which the sample was selected appropriate. Study on the nature of the collection and analysis of data, a combination of quantitative methods with qualitative research method (Shamiq, A. 2009: 60). This methodological approach to our research, more sustainable makes arguments that arise in his conclusion, regarding the factors that affect the implementation of differentiated teaching strategies with children with learning difficulties. The instruments that we use in research are: a) questionnaires; b) Interviews; and c) Focus Group; (Mattheus, B; Ross, Liz; 2010: 201).

\subsection{Selection of Champions}

The population selected in this search are teachers of primary and lower secondary education, as well as school psychologist and 
lecturer. Limited sampling in the Municipality of Pristina and its environs. Stratification of the sampling is done by two groups:

- Rural - urban

- Private school - public school

Weighing scale sampling is done on the basis of approximate participation of these groups in the sample population. Selection of respondents within Strata weighted methodology made by chance (the algorithm randomly in the population register).

Rough stratification of the population division of teachers: The survey was conducted in three schools in Prishtina (urban location, both public and private schools), as well as three schools in rural locations; 75 teachers of primary and lower secondary education were surveyed in three public schools, and 25 teachers of primary and lower secondary education were surveyed in a private school in the city, the total urban location were 100 respondents. While 40 surveys of teachers in primary and lower secondary education are made at three public schools Pristina district (rural). A total of 140 respondents. Circle from the selected sampling was done intentionally, because the city of Prishtina is the place where investing more about the training of various teachers, equipping schools with diverse, in cooperation with parents, in order to raising the quality of teaching and learning, as well as private schools are functional and psychological services of teaching in some schools, which all of these elements may be indicative for successful implementation of teaching differentiated children with learning difficulties.

For conducting interviews was selected sampling intentional composed of psychologists and teachers of schools, in schools where it is functional service (private school) champion deliberately focused on those schools where the number of students is very large, and the number children with $\mathrm{SN}$ is considerable. Also, focus groups were selected for intentional sample consisting of teachers with long work experience and training in this field, but also in the classroom teachers who have a considerable number of children with $\mathrm{SN}$.

\subsection{Instruments Used in the Study}

For lighting empirical problems, differentiated teaching strategies with children with learning difficulties are using these tools:

Questionnaire: In most studies in the social sciences, are advised to use the survey with self-report of which may include different instruments (Mattheus, B; Ross, Liz; 2010: 202). In this study we drafted a questionnaire, which consisted of two sections. In the first section of the survey were put questions about the teacher data such as gender; the level of education achieved; location of school; and the type of school where he works. Except that these data were used as variables in the analysis of data were also used to create a profile of teachers participating in the study. While the second section of the survey is composed of 17 specific questions, through which we aimed to measure the knowledge and assessment of teachers of the benefits of teaching differentiated compared to other types of teaching conditions in schools and readiness their implementation of this mode.

\section{Teaching Differential - Definition}

"The essence of teaching is differentiated adaptation of the contents, processes, methods, forms, techniques, tools, procedures and educational materials styles, intelligences, and the pace of learning of students with the aim of achieving the same goals and objectives" (Muka, P; Karaj, Dh; Qela, L. 2002: 9).

Now the all public opinion is aware that the school has students with learning difficulties, and therefore must find ways to bring assistance to them (Kraja, M. 2006: 287). Given the fact that this mode of teaching us is an innovation in terms of terminology, but not its implementation, since it has been in education ever, even from infancy before, without names or designations different.

Its implementation has been an integral part of the school, where classes held respectively in this process, because it was necessary, until the teacher thought and decided not only to the entire class, but also for special students. Students have always been different because: (from parents, family circles different interests and different needs, difficulties, styles and intelligences different), but the whole problem is how much and how considering the diversity of students in our schools, against the goals and objectives that society puts school.

Experience shows that the higher that the intended performance collective, the more deficient del working only with the entire class, and the more necessary is done taking into account the diversity of students in the design and content, the selection of methods, forms, tools, techniques, procedures and educational materials that are used to adapt rhythms, styles, intelligences, and other differences of students, in order to alleviate or eliminate the overall difficulties facing children in the learning process knowledge, creating habits, and skills development. These are the reasons that necessarily must implement differentiated mode of teaching in our schools (Muka, P; Karaj, Dh; Oela, L. 2002: 10).

Below we give a scheme which sets out the fundamental difference between traditional teaching, with differentiated, as above noted in a wider specifics of teaching indirectly, that there is so fundamental difference teaching differentiated, as has differences traditional teaching mode. 


\begin{tabular}{|c|c|}
\hline \multicolumn{2}{|c|}{ Differences of traditional teaching with differentiated } \\
\hline Traditional & Differentiated \\
\hline $\begin{array}{l}\text { Masked differences between students, or leave when they become } \\
\text { problematic, and thus they can not be resolved. }\end{array}$ & $\begin{array}{l}\text { Differences between students studied to serve as a basis for } \\
\text { successful planning in the education process }\end{array}$ \\
\hline $\begin{array}{l}\text { Evaluation is common and the end of learning is to understand, } \\
\text { who understand it }\end{array}$ & $\begin{array}{l}\text { The assessment is a diagnosis action and made to understand in } \\
\text { what way will adapt teaching to the needs of the learner, taking } \\
\text { into account any difference to children in the educational } \\
\text { process. }\end{array}$ \\
\hline $\begin{array}{l}\text { It dominates a narrow conception of intelligence and other } \\
\text { differences that have children }\end{array}$ & $\begin{array}{l}\text { It focuses on multiple forms of intelligence, and takes into } \\
\text { account any differences that have children in the learning of } \\
\text { knowledge }\end{array}$ \\
\hline Prevails a simple definition for excellence & $\begin{array}{l}\text { Perfection is defined primarily as a development that departs } \\
\text { from the starting point. }\end{array}$ \\
\hline Interests and needs of students are often not taken into account & $\begin{array}{l}\text { Students occasionally led to the fulfillment of their interests and } \\
\text { needs, based on learning needs. }\end{array}$ \\
\hline Considered relatively few options for learning profiles & Profiles observed many learning options. \\
\hline $\begin{array}{l}\text { Dominates the whole class teaching, regardless of the changes that } \\
\text { have children in the learning process }\end{array}$ & $\begin{array}{l}\text { Numerous measures in teaching, making it possible for each } \\
\text { successful student progress in learning process }\end{array}$ \\
\hline Treatment of teaching from textbooks and curricula determined & $\begin{array}{l}\text { Adaptation of teaching students is regulated by predispositions, } \\
\text { interests and their learning profile }\end{array}$ \\
\hline $\begin{array}{l}\text { It focuses on mastery learning of facts and skills, irrespective of the } \\
\text { conditions. }\end{array}$ & $\begin{array}{l}\text { Learning focuses on the use of the most essential skills in order } \\
\text { to develop a coherent understanding of the content and its } \\
\text { reasoning }\end{array}$ \\
\hline $\begin{array}{l}\text { Evaluation forms are unique and dominates the use of an instrument } \\
\text { for assessing student achievement }\end{array}$ & Constantly used many ways assessmen \\
\hline Use of time is less flexible & $\begin{array}{l}\text { Time used flexibly in accordance with students' needs and } \\
\text { interests of students. }\end{array}$ \\
\hline $\begin{array}{l}\text { Only a text prevails, not given alternative opportunities to increase } \\
\text { resources easier learning content }\end{array}$ & $\begin{array}{l}\text { Materials are diversified in order to meet the needs, interests, and } \\
\text { simplification of curriculum content }\end{array}$ \\
\hline Mechanical limited in content acquisition and interpretation of facts & Become common multiple angles of ideas and events \\
\hline The teacher guides the behavior of students. & $\begin{array}{l}\text { The teacher supports habits that help students increase } \\
\text { confidence in themselves. }\end{array}$ \\
\hline Teacher solves problems & Students help each other and the teacher to solve problems. \\
\hline $\begin{array}{l}\text { The teacher drafts standards for the advancement of the whole } \\
\text { class. }\end{array}$ & $\begin{array}{l}\text { Students work with teachers to put together the goals of learning } \\
\text { for all grade and by individuals. }\end{array}$ \\
\hline In most cases using only one form of assessment. & Students are assessed in many ways. \\
\hline
\end{tabular}

\subsection{Strategies for Teaching the Differential}

The basic prerequisites for a differentiated treatment of children with learning difficulties (identification of needs and implementation of appropriate strategies)
In connection with the basic prerequisites to differential treatment of children, it is necessary to be identified them, according to these criteria:

1. Identify students who have learning disabilities; 
2. Recognition in anatomic-psychological development of the child, advancing with difficulty;

3. Recognition of mental-intellectual capability;

4. Recognition of educational and cultural conditions and social and material conditions in which the child;

5. Date on the condition of the senses of sight, hearing (Kraja, M. 2006: 289)

After the teacher has the knowledge easier to take steps that will mitigate or even eliminate entirely difficult to have children in the acquisition of any of the fields or program content.

\section{Findings and Results of Data}

\subsection{The Results of Quantitative and Qualitative Data}

Metrology core of this study is based on the selection of the study sample by randomly. This means that there is no difference or criteria that determine the selection of respondents - or that each interviewee has the same probability of selection. In this way, the results of the sample statistics are valid for the population studied, in this case the Municipality of Prishtina teachers. Random selection is the method applied by the lottery. Teacher Registry is assigned a serial number, and then by the logarithm of chance (in Microsoft Excel program) is generated community numbers selected at random. It should be emphasized that this method is applied after determining the strata of the population, according to the study objectives (location where it operates, as well as the type of school). Sample weights are predetermined by observation of the actual weights in the population strata. Therefore, weight has become a priori the number of respondents, and all analysis results within the group then developed (angl. Pooled).

This strict selection protocol sample was applied in order to comply with the conditions for statistical interference, emanating from the central limit theorem and the law of large numbers. The sample size is selected, within budgetary limits, recognizing the error margin of $5 \%, 10 \%$ confidence interval, in a population of 1427 teachers in the municipality of Pristina. According to the program for calculating Raosoft enough sample size, the sample is supposed to be interviewing 156 attempts, with the assumption that $66 \%$ will respond positively to the request to be interviewed. After the interview, the response rate has proved to be $71.7 \%$, that of 156 requests, 112 teachers have agreed to be interviewed. Stratification and weight of the sample was made ex-ante, where separation is proportional to the number of schools and teachers engaged in school, among the 17 public schools and 5 private schools in urban areas (with over $65 \%$ of teachers engaged) and 24 public schools in rural areas.

The entire questionnaire is designed to answer categorical / ordinal, to accelerate the time of the survey and to increase the accuracy of the answers given. All answers given are included under the pre-encoded data in order to avoid errors. As a database, as well as the overall statistical analysis was performed by SPSS 17.0 statistical program. Although he collected data derived from ordinal response, the statistics presented are derived from the frequency percentage categories. The categories are designed to be exclusive, which means that only one option was applicable to respondents, it is therefore a direct interpretation (see the questionnaire in the Annex).

In statistical testing phase two tests were used. Univariat test is used as a binomial test of proportion, as in the bivariate case is using Chi-square test (angl. Pearson Chi Square). The significance level predefined in both these tests is selected $5 \%$. Statistical analysis of the data is divided into the descriptive analysis, and testing it. In the first part of the analysis presented basic information on the demographics of teachers and basic statistics drawn from teachers' responses to questions via questionnaires. In the second half then proceed with statistical hypothesis testing study, which analyzed the responses of teachers being conditional on their demographic differences, gender, the environment where it operates schools, education level and the type of school where the teacher works.

It should be emphasized that the descriptive statistics analysis constantly refer to the outcomes of the sample observations. Given that the sample selection is made exclusively randomly, these results can be used for statistical interference within the selected population - ie teachers in the municipality of Pristina. Given the budget limitations of this study - namely limiting the number of respondents - statistical interference should be interpreted with caution.

\subsection{Quantitative Analysis of Data}

Discussing the results of the study aims to identify the realization of the purpose of this study regarding teaching strategies differentiated children with learning difficulties, and the hypotheses raised in the study, if the teaching of differentiated accompanied associated with difficulty lower learning, compared with other types of teaching. Factors analyzed in the context of this study will be analyzed with each other, because to us so far no in-depth studies on teaching strategies differentiated children with learning difficulties, which can be compared with research previous. 


\section{Regarding the basic hypothesis:}

Differentiated instruction and individual influences more in overcoming difficulties in learning, compared with other types of teaching.

In this study we were worked with various teachers like (different levels of education, with different specifications, such as the type and location of the school where they work, as well as work experience and trainings attended). The analysis of measurement data it was found that no statistically significant differences between them with regard to the first hypothesis.

\section{Basic statistical hypothesis Examination:}

From the presentation of the results of the analysis descriptive, can already be concluded that according to the teachers of the Municipality of Prishtina (with interference) teaching differentiated and individual associated with less difficulty in learning, compared with other types of teaching - scale adoption of $72.1 \%$.

Since all the answers in this study were designed according to the survey to be categorical, analysis of variance responses has no statistical significance. However, responses to the questionnaires are ordinal, so they were given from 1 to 5 in case the main question. In the context of the question of the effect of differentiated teaching degree this is translated in accordance with the conclusion, ie 1 (least) to 5 (completely). Just because observation, statistical analysis results in an arithmetic average of 4:05 (more than evaluation agree ,too" with a standard deviation of 0.8 (according to the response rates).

To formally test the hypothesis of the study, the variable interest values are reconstructed into a binary variable, where the value 1 is defined ,, success "or the teacher agrees ,, very" or ,, fully "with the hypothesis, or 0 as, , non-success "where the teacher has given approval lesser extent, somewhat ,", ,, little "or ,, no". Taking into account the available data that represent ordinal ratings, such a reconstruction of the variable allows for the use of binomial proportion test through statistical z. We note that in case of noncategorical variables, it would be standard for such purposes to be used, test ".

\section{In this form to conclude that quantitative goals:}

"More than 2/3 of teachers in the municipality of Pristina estimate that differentiated and individualized teaching is associated with less difficulty in learning, compared with other types of teaching "

\section{Statistical test:}

The value of the test binomial proportion is lower than 1\%, meaning much lower than the margin of permissible error of $5 \%$, therefore we can conclude that there is no statistical evidence to reject the hypothesis, and conclude that differentiated teaching is more effective than the current format.

Through this test statistic proved that even if the conditions hypothetical interview will be repeated with other samples representative within the population (teachers and Pristina), randomly, then the proportion who appreciates the usefulness of teaching differential will still pass two thirds of respondents.

\section{Auxiliary hypotheses:}

To better inform understanding of the basic hypothesis in this study were also presented four auxiliary hypotheses which are examined statistically as:

1. Gender teacher determines the differences in evaluating the effectiveness of differentiated teaching;

2. The level of education of teachers determines their differences about the usefulness of differentiated teaching;

3. Type of school determines the difference in knowledge, and the willingness of teachers to implement differentiated instruction;

4. Determines the difference in knowledge, and assessing the utility of teachers for the implementation of differentiated teaching

The importance of these auxiliary hypotheses is more detailed understanding of the determinants of attitudes towards differentiated instruction, and the differences have statistical significance can then be used to formulate recommendations for the improvement of teaching method differentiated educational system

\section{Auxiliary Hypothesis 1:}

Gender teacher determines the differences in evaluating the effectiveness of differentiated teaching;

1. From the data presented in the following tabulation variable that defines the basic hypothesis with variable gender of respondents, it appears that there is a higher probability that male teachers teaching to estimate the benefits of differentiated than the opposite sex. While $68 \%$ (56 of 82 ) females have considered teaching differentiated form followed with fewer difficulties in learning, $80 \%$ ( 24 of 30 ) of male teachers are given the same rating. 
Table 1. Tabulation, high degree of compliance with the basic hypothesis "to,, Gender of Teacher"

\begin{tabular}{|c|c|c|c|c|}
\hline \multirow{2}{*}{\multicolumn{2}{|c|}{$\begin{array}{l}\text { Tabulation,, high degree } \\
\text { of compliance with the } \\
\text { basic hypothesis "to,, } \\
\text { Gender of Teacher" }\end{array}$}} & \multicolumn{2}{|c|}{ Gender of Teacher } & \multirow[b]{2}{*}{ Total } \\
\hline & & Female & Male & \\
\hline \multirow{2}{*}{$\begin{array}{c}\text { The high level } \\
\text { of compliance } \\
\text { hypothesis }\end{array}$} & $\begin{array}{c}\text { No } \\
\text { success } \\
(\mathrm{NO})\end{array}$ & 26 & 6 & 32 \\
\hline & $\begin{array}{c}\text { Succes } \\
\mathrm{s} \\
\text { (YES) }\end{array}$ & 56 & 24 & 80 \\
\hline Total & & 82 & 30 & 112 \\
\hline
\end{tabular}

\section{Statistical Test:}

Formal statistical hypothesis testing of the first auxiliary through Chi-Square statistical test shows that despite the fact that the descriptive analysis of the results seems to have a tendency to male teachers have the highest rating for the benefit of differentiated teaching; Gender differences were not statistically significant rating. $P$ value of the test statistic is 0.225 , indicating that there is $22.5 \%$ probability of receiving an erroneous hypothesis, well above the predetermined threshold with this study of $5 \%$.

\section{Auxiliary hypotheses 2:}

The level of education of teachers determines their differences about the usefulness of differentiated teaching;

Regarding the difference in the evaluation of teaching differentiated by teachers, conditional on their level of education, tabulation of the data shows that the trend higher to assess the usefulness of teaching differentiated show teachers who have completed level Master education (19 of 22, or $86 \%$ ). However, the relationship is not linear, because the trend is higher among teachers with HPS than those with Bachelor-level education, $69 \%$ to $67 \%$ respectively.
Table 2. Tabulation, high degree of compliance with the basic hypothesis "to,, education level of teachers'

\begin{tabular}{|c|c|c|c|c|c|}
\hline \multirow{2}{*}{\multicolumn{2}{|c|}{$\begin{array}{l}\text { Tabulation,, high degree of } \\
\text { compliance with the basic } \\
\text { hypothesis "to,, education } \\
\text { level of teachers' }\end{array}$}} & \multicolumn{3}{|c|}{$\begin{array}{c}\text { The level of education of } \\
\text { teachers: }\end{array}$} & \multirow[b]{2}{*}{ Total } \\
\hline & & $\mathrm{H}$ & Faculty & Master & \\
\hline \multirow[t]{2}{*}{$\begin{array}{c}\text { The high level } \\
\text { of compliance } \\
\text { hypothesis }\end{array}$} & $\begin{array}{l}\text { Non- } \\
\text { success } \\
\text { (NO) }\end{array}$ & 10 & 19 & 3 & 32 \\
\hline & $\begin{array}{c}\text { Success } \\
\text { (YES) }\end{array}$ & 22 & 39 & 19 & 80 \\
\hline \multicolumn{2}{|c|}{ Total } & 32 & 58 & 22 & 112 \\
\hline
\end{tabular}

\section{Statistical Test:}

However, as in the case of teacher gender, education level of teachers it appears that is not statistically significant, despite the observable differences in sample results. P value of statistical test Chi-Square is 0.221, indicating high probability that the hypothesis is not true (22.1\% probability).

\section{Auxiliary hypotheses 3:}

Type of school: Determines the difference in knowledge, and the willingness of teachers to implement differentiated instruction;

More pronounced differences in assessing the usefulness of the resulting differentiated teaching evaluations after conditioning with variable type of school where the teacher is engaged. While the tendency of all teachers engaged in private schools is to evaluate the usefulness of teaching high differential ( 27/27), it is lower tendency to engage teachers in public schools ( $53 / 85$ or $62 \%)$.

Table 3. Tabulation, high degree of compliance with the basic hypothesis "to,, Type of school where the teacher works"

\begin{tabular}{|c|c|c|c|c|}
\hline \multirow{2}{*}{\multicolumn{2}{|c|}{$\begin{array}{l}\text { Tabulation,, high degree } \\
\text { of compliance with the } \\
\text { basic hypothesis "to,, } \\
\text { Type of school where the } \\
\text { teacher works" }\end{array}$}} & \multicolumn{2}{|c|}{$\begin{array}{c}\text { Type of school where the } \\
\text { teacher works }\end{array}$} & \multirow[b]{2}{*}{ Total } \\
\hline & & Public & Private & \\
\hline \multirow{2}{*}{$\begin{array}{c}\text { The high level of } \\
\text { compliance } \\
\text { hypothesis }\end{array}$} & $\mid \begin{array}{l}\text { Non- } \\
\text { success } \\
\text { (NO) }\end{array}$ & 32 & 0 & 32 \\
\hline & $\begin{array}{l}\text { Succes } \\
\mathrm{s} \\
\text { (YES) }\end{array}$ & 53 & 27 & 80 \\
\hline \multicolumn{2}{|l|}{ Total } & 85 & 27 & 112 \\
\hline
\end{tabular}




\section{Statistical Test:}

Formal testing of observations arising from the results of sample hypothesis that private school teachers have a higher rating than those of public schools for teaching differential is statistically significant. P value of Chi-Square test is the 0.00, indicating that there is the probability that the hypothesis is much lower than the predetermined margin of 5\% (0:05).

\section{Auxiliary hypotheses 4:}

School location: Determines the difference in knowledge, and assessing the utility of teachers for the implementation of differentiated instruction;

The type of location where it operates schools in which the teacher is engaged, there is significant difference in knowledge and appreciation of the benefits of differentiated teaching. More specifically, teachers engaged in the city have knowledge, but also a significantly higher tendency $(57 / 71$ or $80 \%)$ to assess the usefulness of teaching differentiated compared to teachers engaged in rural location $(23 / 41$, or $56 \%)$.

Table 4. Tabulation, high degree of compliance with the basic hypothesis "to,, location of the school where the teacher works"

\begin{tabular}{|c|c|c|c|c|}
\hline \multirow{2}{*}{\multicolumn{2}{|c|}{$\begin{array}{l}\text { Tabulation,, high degree } \\
\text { of compliance with the } \\
\text { basic hypothesis "to,, } \\
\text { location of the school } \\
\text { where the teacher } \\
\text { works" }\end{array}$}} & \multicolumn{2}{|c|}{ School Location } & \\
\hline & & Village & City & Total \\
\hline \multirow{2}{*}{$\begin{array}{c}\text { The high level } \\
\text { of compliance } \\
\text { hypothesis }\end{array}$} & $\begin{array}{l}\text { Non- } \\
\text { succes } \\
\text { s (NO) }\end{array}$ & 18 & 14 & 32 \\
\hline & $\begin{array}{c}\text { Succes } \\
\mathbf{s} \\
\text { (YES) }\end{array}$ & 23 & 57 & 80 \\
\hline \multicolumn{2}{|l|}{ Total } & 41 & 71 & 112 \\
\hline
\end{tabular}

\section{Statistical Test:}

Even in the case of hypothesis 4-of ancillary testing shows selokacioni school formal is definitive evaluation of the usefulness of differentiated teaching. $P$ value of the test statistic is 0.006, which means that the probability of error in accepting this hypothesis is only 0.6\%, significantly below the accepted margin of $5 \%$.

\section{Conclusions and Recommendations}

The findings of the study gave positive answers the first research hypothesis that differentiated instruction is a priority in children's learning with vësntirësi, compared with other types of teaching. Study on differentiated teaching strategies in children with VN is one of the few studies done in Kosovo, which illuminates some interesting opinions discussed in the study. These represent opportunities, interventions for positive change with regard to the implementation of differentiated teaching strategies in order to mitigate or eliminate entirely the problems faced by children with $\mathrm{VN}$ in the teaching process. The benefits of such teaching will be to the benefit of all children, especially children with VN, parents and society in general. Such changes would make our goal a reality of our society that every citizen to ensure quality education regardless of their differences in the development of individual, national differences, religious, gender, race etc.

\section{Some recommendations for education policy and decision} makers are:

Invest in regulation and the expansion of facilities where learning takes place;

- Invest in all schools in technology (means) varied learning (visual, auditory, visual);

- The functional pedagogical and psychological services in schools.

- Improve efficiency of teacher training system.

For this:

- Push materially and encouraged to attend properly to take advantage of training to raise the quality in their work with all groups of children;

- Include in the training which focus on pedagogical and psychological themes, such as the difficulties in learning to children;

- The funded publications which reflect the concerns of teachers in learning difficulties in children, as well as successful strategies to approach the work in these groups of children.

\section{Recommendations for schools:}

- Schools should explore the possibilities of the device with multiple tools and opportunities to use ICT to create a variety of teaching, in order to facilitate the learning of children, in particular children with $\mathrm{SN}$;

- The animated function within training schemes, with special focus on treatments to problems with learning difficulties in children; 
- To explore the way to permanent cooperation with parents, with the aim of unifying the attitudes and views concerning the treatment of children with $\mathrm{SN}$.

\section{Recommendations for teachers:}

- Teachers need to implement differentiated teaching to achieve results satisfactory to all children;

- The problems of children in learning can be a reflection of inappropriate teaching practices;

- Teachers need to recognize, interests, styles, intelligences and difficulties of each child in the implementation of differentiated teaching, trusting in the abilities of each child;

- Teachers must be informed of the reasons of learning difficulties, type, characteristics of children with $\mathrm{SN}$ that can build successful strategies;

- Teachers should consult with pedagogical and psychological service for more in-depth knowledge of learning difficulties in children, as well as possibilities of successful treatment of learning difficulties;

- Apply the exchange of visits classes to exchange positive experiences in terms of learning difficulties

\section{Recommendations for parents:}

- Parents must attend school more often in order to be aware of the problems and difficulties faced by their children in the learning process;

- Parents should consult with teachers tutors and pedagogical-psychological service in order to inform about the situation of the child, as well as opportunities to help children overcome learning difficulties.

\section{References}

1. Muka. P, Karaj. Dh, \& Qela. L, (2002). Hyrje në mësimdhënien e diferncuar, Tiranë

2. QTKA, (2005). Mësimdhënia me në qendër nxënësin

(1), Geer, Tiranë

3. Rraçi. A, Gashi. Sh, (2001). Doracak pune i përgatitjes me shkrim për orën mësimore, Prishtinë

4. Mathews. B, Ross. L, ( 2010 ). Metodat e Hulumtimit, Tiranë

5. Eco. U, (1997). Si bëhet një punim diplome, Tiranë

6. Gjedia. R, (2010). Trajtimi i fëmijëve me vështirësi në të nxënë, Tiranë

7. Tomlinson. C, A, (2005). Fulfilling the promise of the differentiated classrooms, ASCD, Virginia USA

8. Woolfolk. A, (2011). Psikologji Edukimi, CDE
9. Zabeli. N, (2004); Vështirsitë në të nxënë, PrishtinëGërliq Danko, Leksikoni i filozofëve (The lexicon of philosophers) „Rilindja“, Prishtinë, 1986. 